\title{
開発者の視点からの機械翻訳システムの技術的評価 一テストセットを用いた品質評価法一
}

$\begin{array}{lrrrrr}\text { 井佐原 均 } & \text { 内野 } & \text { 一 } & \text { 荻野 } & \text { 紫穂 } \\ \text { 奥西 } & \text { 稔幸 } & \text { 木下 } & \text { 聡 } & \text { 柴田 } & \text { 昇吾 } \\ \text { 杉尾 } & \text { 俊之 } & \text { 高山 } & \text { 泰博 } & \text { 土井 } & \text { 伸一 } \\ \text { 永 野 } & \text { 正 } & \text { 成田 } & \text { 真澄 } & \text { 野村 } & \text { 浩郷 }\end{array}$

機械翻訳システムの開発者がシステムの技術的評価を翻訳品質に注目して客観的に行 う手法を開発した。評価過程の客観性と評価結果の解釈の客観性を維持するために、 本手法では単なる評価用例文集ではなく、システムの出力を評価するための設問と、 その設問がどのような言語現象を対象としているかについての解説とを各例文に付与 したテストセットを用いている。各例文は基本的な言語現象と現在の機械翻訳システ ムにおいて処理が困難である言語現象のそれぞれを出来る限り網羅するように収集さ れた。今回、英日機械翻訳システム、日英機械翻訳システムのそれぞれについての評 価用テストセットを作成した。これらを用いて商用の機械翻訳システムでの評価実験 を繰り返すことにより、機械翻訳システムの能力の差異を提示できることが示された。

キーワード： 機械翻訳, 品質評価, コーパス

\section{Technical Evaluation of MT Systems from the Developer's Point of View: Exploiting Test-Sets for Quality Evaluation}

\author{
Hitoshi Isahara, Hajime Uchino, Shiho Ogino, Toshiyuki OKunishi, \\ Satoshi Kinoshita, Shogo Shibata, Toshiyuki Sugio, \\ Yasuhiro Takayama, Shin'ichi Doi, Tadashi Nagano, Masumi Narita \\ and Hirosato Nomura
}

This paper describes a method of evaluating quality for developers of machine translation systems to easily check imperfections in their own systems. Our method employs test-sets in which example sentences, their model translations, yes/no questions for evaluating the system output, similar examples (if any), and grammatical explanations have been systematically aligned. The example sentences have been collected focusing on wide coverage of both basic linguistic phenomena and linguistic phenomena problematic to MT systems. The questions in the test-sets are designed to clarify the evaluation viewpoints. Given the system outputs for each example sentence in question, the system developer needs only to answer the question assigned to the example sentence. This judgment does not vary among evaluators, thus enabling an objective evaluation.

KeyWords: Machine Translation, Quality Evaluation, Corpus 


\section{1 はじめに}

機械翻訳システムの長い歴史の中で、システム評価は常に大きな課題の一つであった。シ ステムの研究開発が健全に進むためには、客観的かつ正確な評価法が必要となる。このため、 ユーザの立場から評価を行うもの、開発者の立場から評価を行うもの、また、技術的側面から評 価を行うもの、経済的側面から評価を行うものと、多くの研究者によって様々な視点からの評 価法が検討されてきた。これらの検討に基づいて、(社) 日本電子工業振興協会によって一連の 機械翻訳システム評価基準が開発されてきた(野村・井佐原 1992, Nomura and Isahara 1992a, Nomura and Isahara 1992b，日本電子工業振興協会 1993)。本稿で提案する機械翻訳システム の評価法は、システムの改良を続ける開発者の立場から、機械翻訳システムの技術面を翻訳品 質に注目して評価するものである。

機械翻訳システムの訳文の品質面での評価に関しては、従来からのいわゆる A L P A C レ ポート型の評価法に加えて、近年、いくつかの提案がなされている。ある程度まとまった文章 を翻訳し、そこから得られる理解の度合を評価しようとするものとして、A R P Aによる機械 翻訳システム評価 (White et al 1994) や、T O E F Lのテストを用いる方法 (Tomita 1992) が 提案されているが、これらはシステム間の現時点での性能の比較評価には用いることが出来て も、評価結果を直接システム改良に結び付けることは困難である。

これに対し、個別の例文を収集することにより評価用の例文集を作成し、その各例文の翻訳 結果を評価し、対応する言語現象の処理能力を判定しようとする提案がいくつかなされている。 これらのうちには、単に文を集めるのみで、その後の例文の利用法 (評価過程) は個別の評価者 に任せようというものから、本稿で提案するように、客観的評価のためにさまざまな情報を付

0 井佐原均, Hitoshi Isahara, 郵政省通信総合研究所 関西先端研究センター, Kansai Advanced Research Center, Communications Research Laboratory, MPT

0 内野一, Hajime Uchino, 日本電信電話株式会社 NT Tコミュニケーション科学研究所, NTT Communication Science Laboratories, Nippon Telegraph and Telephone

0 荻野 紫穂, Shiho Ogino, 日本アイ・ビー・エム株式会社 東京基礎研究所, IBM Research, Tokyo Research Laboratory, Nihon IBM

0 奥西 稔幸, Toshiyuki Okunishi, シャープ株式会社 情報システム事業本部情報商品開発研究所, Information Systems Product Development Laboratories, Information Systems Group, Sharp Corp.

0 木下 聡, Satoshi Kinoshita, 株式会社東芝 研究開発センター情報・通信システム研究所, Research and Development Center, Communication and Information Systems Research Laboratories, Toshiba

0 柴田 昇吾, Shogo Shibata, キヤノン株式会社 情報メディア研究所, Media Technology Laboratory, CANON INC.

0 杉尾 俊之, Toshiyuki Sugio, 沖電気工業株式会社 研究開発本部関西総合研究所, Research and Development Group, Kansai Laboratory, Oki Electric Industry Co., Ltd.,

0 高山 泰博, Yasuhiro Takayama, 三菱電機株式会社 情報技術総合研究所, Information Technology R\&D Center, Mitsubishi Electric Corp.

0 土井 伸一, Shin'ichi Doi, 日本電気株式会社情報メディア研究所, Information Technology Research Laboratories, NEC Corp.

0 永野 正, Tadashi Nagano, 松下電器産業株式会社 A V \& C C 開発センター東京情報システム研究所, ICSC, Matsushita Electric Industrial Co., Ltd.

0 成田 真澄, Masumi Narita, 株式会社リコー 情報通信研究所, Information and Communication R\&D Center, Ricoh Co., Ltd.

0 野村 浩郷, Hirosato Nomura, 九州工業大学 情報工学部 知能情報工学科, Department of Artificial Intelligence, Kyushu Institute of Technology 
加しようというものまで、いくつかの段階がある。

わが国においては、(社) 日本電子工業振興協会が既に昭和 60 年に機械翻訳例文資料とし て、翻訳における曖昧性に関する問題点に着目して、英文および和文を収集分類し公開してい る (日本電子工業振興協会 1985)。また同協会は昭和 62 年度に、機械翻訳システムの技術レべ ルを評価するために、文の複雑さの定量化、文の複雑さや文体の定性的特徴の抽出、標準的例 文の収集を行なった (日本電子工業振興協会 1988, 石崎・井佐原 1988)。

この他、英語を話す人間と日本語を話す人間との間にある言語理解法の違い（言い替えると、 日本語と英語の発想法の違い) に注目して日本語の言語表現を分類し、それらの表現の翻訳能力 を評価する試験文集を作成するもの (池原・小倉 1990, 池原 他 1994) や、言語学的観点から日 本語および英語の言語表現の構造に注目し、その表現上の構造的特性を的確に表すような試験 文集を作成すること (成田 1988) が提案されてきた。後者は、個々の言語現象に対する翻訳の可 否を示すことの必要性から、一定の内容の文の言い換えなどによって日本語および英語の言語 表現と翻訳能力の関係を言語学者の立場から評価することを提案している。

本稿で論じる機械翻訳システム評価用テストセットは、以上のような、A L P A Cレポート 以来の品質評価に関する研究を踏まえて、誰でも客観的かつ実用的な評価を行なえる評価法の 確立を目指し作成したものである。次節以下では、テストセットを用いた評価法の全体を流れ る基本的な考え方、英日機械翻訳用テストセット、日英機械翻訳用テストセットについて、順 次説明していく。

\section{2 テストセットを用いた機械翻訳システムの品質評価法}

\section{1 本評価法の利点}

これまで、機械翻訳システムの品質評価法として種々の方法が提案されているが、それ らの方法に関しては一貫して客観的評価が困難であるという指摘が行なわれてきた。本稿で はまず、従来までの評価法と比べての本評価法の利点を、以下の二つの客観性に基づいて検討する。

(1) 評価過程が客観的であること

(2) 評価結果の判断が客観的に行なえること

たとえば、AＬＰＡＣレポート等に代表される評価法は、評価の軸として「忠実度」「理解 容易度」といった、その解釈が評価者の主観的判断に依存する基準を採用している。その結果、 評価結果が評価者によって大きく異なってしまうという問題があり、(1)の客観性を満たして いない。この評価のばらつきは不完全な翻訳結果を評価する際に特に顕著に現れるが、現実の 機械翻訳システムを評価し、開発過程にフィードバックする際には、翻訳に成功した場合より 
も失敗した場合についての検討が重要である。

この種の評価法においては評価結果は数值で表現されているため、ある意味では、(2)の客 観性を満たしているともいえよう。しかしながら開発者にとっては、自己のシステムが、どの 言語現象をどの原因によって処理できなかったのかを判断することが特に重要であり、言語現 象が複雑に絡みあった文の翻訳結果を単純に得点化するだけでは有効とはいえない。システム 改良に用いるためにその評価結果を解釈しようとする場合には主観的な判断に頼らざるを得な いので、実用的にはこの評価法は $(2)$ の客観性を満たしているとはいえない。

一方、我々の開発した評価法においては、これら二つの客観性は共に保たれている。ここで は、単にそれに答えるだけで、システム開発者が自己のシステムの性能評価を行なえるように 作られた yes/no 設問を各例文に付加することにより、翻訳結果を評価する手続きを明確化し た。評価過程で必要とされる手順は単純な yes/no 疑問文に答えることだけであり、誰でも機械 翻訳システムを同様に評価することが出来る。不完全な翻訳文に対しても、評価者によって評 価が大幅に変わるということはない。

さらに、各例文には翻訳処理と言語現象との関係を表す解説が付加されており、これによ り、システム開発者はなぜ自己のシステムが問題の言語現象を正しく解析できないのかを知る ことが出来る。すなわち、我々のテストセットに基づく評価結果を用いて、機械翻訳システム の改良法を決定することが出来る。

機械翻訳システムの評価に関しては、既に述べたように、評価すべき言語現象を含む文を 集めた評価用例文集の作成という試みもなされている（成田 1988, 池原・小倉 1990 , 池原他 1994)。

このような例文集を用いれば、もしシステムが、ある例文を正しく翻訳できないと評価され た場合には、システム開発者はただちにその例文が問題としている言語現象をそのシステムが 処理できないということが分かる。この点において、この手法もまた $(2)$ の客観性を保持して いる。しかしながら、この手法には以下の二つの問題がある。

・ 例文の翻訳結果を評価する手順が明示されていない。

・評価結果から機械翻訳システムの不備な点を見つけ出す過程が評価者の言語直観に頼つ ている。

例文を集めただけのもの（テストスゥイート(Test Suite)) では、個々のシステムの ad hoc な評価は可能であっても、評価法としては確立しない。明確に記述された手続きにしたがって、 誰でも同じように機械翻訳システムを評価できることが必要である。この目的のために各例文 に設問や訳出例を付与しているということを明確にする意味で、我々の評価法においては「テ ストセット (Test Set)」という名称を用いている。 
また、評価結果を機械翻訳システムの改良に用いるためには、さまざまな言語現象を単に羅 列しておくだけでは不十分である。文法体系の中での各言語現象の位置づけを明確にしておく ことも必要である。

このような考察のもと、我々は上で述べた評価過程の客観性と結果の判断の客観性という二 つの客観性を追求した品質評価を可能とする品質評価用テストセットを提案してきた。ここで 用いるテストセットは、考慮すべき文法項目を系統立てて収集し、その各項目に例文を付加し て作られた。各例文に解説や設問を付加することによって評価の手順を明確に記述することが 可能となった。

各テストセットには、評価用例文、その人間による模範訳、システムの出力 (翻訳結果) を 評価するための設問などが記述されており、評価者はテストセット中の例文を翻訳し、その翻 訳結果を参照しながら各例文に付与された設問に回答していく。ここで各設問は判断のポイン ト (すなわち、例文のどの部分が、どのような役割で、どのような訳文となっていれば良いか) が明示された yes/no 質問文であり、評価者によって判断が異なることがないように作られてい る。この判断をさらに容易にするために、既存の機械翻訳システムでの翻訳結果を用いた回答 例が付与されている。以上により評価過程の客観性を実現している。また、各例文には、その 文がどのような言語現象を評価するためのものであるかを説明する解説が付与されており、開 発者はその例文に対する翻訳結果から自己のシステムが十分には対応していない言語現象を容 易に理解することが出来る。これにより、評価結果の判断の客観性を実現できる。

\section{2 本評価法の基本的立場 (どのような情報を開発者に与えるか)}

この評価用テストセットは、個々の機械翻訳システムに依存しない汎用の品質評価法として 作成している。したがって、対象とするシステムがルールベース・知識ベース・用例ベース・直 接型といった機械翻訳のどの手法を採用しているかには依存しない。このテストセットの目的 は機械翻訳システムの開発者が自己のシステムの性能を向上するために、システムの処理でき ない言語現象を正確に把握することである。その言語現象を処理可能にするための手法は、個々 のシステムあるいは個々の手法によって異なっており、その判断は開発者に任すこととし、評 価基準としては、そこには立ち入らない。用例ベースの手法とルールベースの手法に共通する 解決策を評価法が示すということは現実的ではない。

また、個々のシステムによって、対象とする文書が異なっており、各言語現象の出現頻度も 異なっている。したがって、システムの欠点のうちで、どの欠点が最も重大であるかを決定す ることは、当事者にのみ可能なことである。本テストセットの目標は、その当事者の判断を可 能な限り援助することにある。ここではテストセット中の各例文には、頻度に関する情報を記 述するのではなく、その例文が判断する言語現象を記述してある。翻訳対象となる文書が特定 の言語現象に偏っている場合には、評価者はこのテストセットのうちで、必要な言語現象に対 
応する部分についてのみ翻訳し、その結果を評価すれば良い。自分にとって重要な言語現象を 取り扱えるかどうかが、個々の開発者あるいはユーザがシステムを評価する場合には重要であ り、評価法としての独自の頻度による一般的な得点化を行なうのは、むしろ誤った評価の原因 になると考える。

また、評価に例文を用いることについては、その例文に対して高い評価が出るようにシステ 厶を修正することが可能であること、また、全ての言語現象を網羅できるわけではないことな どの問題点が指摘される。しかしながら、ここで提案する評価法はシステム間の相対的な性能 評価のために用いるものではない。開発者が自己のシステムの改良のために、その久点を把握 することが目的であり、この本来の目的のためには本テストセットに対してチューニングをす ることに意味はない。また、本テストセットは単なる例文集ではなく、各例文にはその対象と する言語現象が解説されており、さらには必要に応じて関連文と、その模範訳が付加されてい る。これらの文を翻訳し検討することにより、単に一つの例文を処理できるかどうかを判断す るだけではなく、その例文に関連する言語現象についての処理能力も知ることが出来る。

さらに、個々の開発者が処置するべき問題として、テストセット中の例文に存在する未定義 語の問題がある。例文中に(そのシステムにとっての) 未定義語があった場合には、評価者は例 文中に現れた未定義語を辞書登録するか、あるいは例文中の未定義語を既にシステムに登録さ れている類似の単語に変更することが要求される。繰り返すが、この評価法はシステム間の優 劣を決めることが目的ではなく開発者が自分のためにシステムの欠陥を見つけて、それを修正 することを主なる目的としている。したがって、評価者 (すなわち開発者) は単純に評価結果を 受け入れるのではなく、「翻訳に成功しているが偶然良い訳語が記述されていただけだ。」「翻訳 に失敗したが、それはその単語が未定義であったためで、類似の現象自体は取り扱う能力があ る。」等については、各自の (自己のシステムについての) 知識に基づいて判断する必要がある。

また、評価の結果、さまざまな欠陥が見つかった場合に、限られた人的資源の中で、どのよ うな順序でそれを解決していくかという問題もある。しかしながら、各開発者毎に資源の制約 や、そのシステムが主として対象とする文書 (あるいは、対象とする言語現象) が異なるため、 一般的な優先順位を予め定めておくことは現実的ではない。本テストセットは、比較的近い将 来に正しい処理の実現が可能な言語現象に重点をおいて作っているが、取り扱えなかった言語 現象の内で、まずどの現象を処理可能にするかという優先順位付けは、個々のシステムの開発 者に任せられている。

なお、このように近い将来に対応できるものに重点を置いて言語現象を収集しテストセット とした場合、機械翻訳システムの技術水準の向上に伴って、対象とする言語現象を継続的に追 加あるいは削除していくことが望まれる。常にその時点で機械翻訳において問題となっている 言語現象を１００００文程度のテストセットで示すのが理想であろう。ただし、最低限の解析能 力を試すための基本的な構造の文は現在も(そのような基本的な構造の解析は既にほとんどの 
システムにおいて解決されている問題であるとしても) テストセット中に含まれている。このよ うな基本文はシステムの最低水準を保証するものとして、将来に瓦ってもテストセットに含ま れると想定している。

\section{3 評価用例文の収集}

テストセットの例文は機械翻訳システムや自然言語処理システムを実際に開発してきた経験 に基づいて、著者らによって収集された。例文の収集に当たっては、我々は以下の 2 点を重視した。

(1) 基本的な言語現象を網羅すること。

(2) 機械翻訳システムにとって処理することが困難な言語現象を含む例文を選択すること。

ここでは特に曖昧性の問題を重視した。

言い替えると、（1）は評価すべき文法現象を系統立てて収集分類 (トップダウンの手法) し、 それらの現象に対応する例を集めることである。一方 $(2)$ は機械翻訳システムによって翻訳 することが困難であるような例文を収集する (ボトムアップの手法)ことである。特に我々は 処理の困難さが近い将来に解決できるであろうような言語現象に注目した。そして機械翻訳 システムの評価のための例文を系統立てて分類した。さらに、我々はこれらの例について、い くつかの商用システムを用いて翻訳評価実験を繰り返し、テストセットを以下の点に焦点を 当てながら改良した。これらは全て、評価過程において客観性を維持するために重要な要素である。

・設問に曖昧性がないこと

- 例文に不必要な複雑さがないこと

- 翻訳結果に曖昧性がないこと

なお、テストセット中の英文は、その英語としての品質を保証するため、英語を母国語と し、日本語を理解する自然言語処理研究者によって、チェックされ修正された。

なお、このテストセットを用いた品質評価法の提案の主旨と、作成の詳しい経緯については、 参考文献 (井佐原 他 1992, 日本電子工業振興協会 1993, 日本電子工業振興協会 1994, Isahara et al 1994, 日本電子工業振興協会 1995a, Isahara 1995) を参照されたい。また、テストセットの 全容は、参考文献 (日本電子工業振興協会 $1995 b$ ) に示されている。 


\section{3 英日機械翻訳システム品質評価用テストセット}

本節では、英日機械翻訳システムの品質評価用テストセットについて説明する。このテスト セットは、機械翻訳システムが処理すべき様々な言語現象を含んだ英語例文 770 文とその模範 訳、及びシステムの出力 (翻訳結果) を評価するための設問などからなる。

\section{1 概要}

我々は、英日機械翻訳システムの評価基準として、システム開発者が自己のシステムの不備 をチェックすることを主要目的とした品質評価用テストセットを作成した。本テストセットに おける例文の収集に際しては、「基本的な言語現象を網羅すること」「機械翻訳システムが取り 扱うことが困難な言語現象を、主に曖昧性の解消に注目して収集・分類すること」を試みた。 また、システムの出力 (翻訳結果) を見ながら回答していくことで品質に関する客観的な判断が 可能となるように、各文に判断のポイントを明示した yes/no 疑問文の形式の設問を付与して いる。このように本テストセットは客観的な品質評価の実現を目指して作成したものなので、 ユーザが各機械翻訳システムの出力品質を比較する際に利用することも可能である。

本テストセットの作成作業は、平成 4 年度からの 3 年間で行った。平成 5 年度末までに第 1 段階として、英語の単文を中心に評価すべき項目を抽出して評価基準を設定し、309の基本例 文を収集・評価して「電子協平成 5 年度版テストセット」としてまとめた。これに加えて、今 回さらに以下の作業を行って項目の充実を図った。

- 平成 5 年度版テストセットが単文中心だったのに対して、接続詞、関係詞、比較、話法、 挿入、並列など、より複雑な構造を持つ複文・重文に関連する項目を重点的に英文法の 解説書などから抽出して収集

・ 複数の文法書などを参考にすることにより、単文内の項目に関しても、平成 5 年度版テ ストセットでカバー出来ていない項目を収集。特に、代名詞、前置詞、記号、数量表現 などに関して新規の設問を多数作成

- 文法項目の洩れを防ぐため、英字新聞から英文テキスト 300 文を選出して市販の英日機 械翻訳システムで試訳し、翻訳が困難となる問題点を抽出

上記の作業により、これまでの 309 項目と併せて延べで約 1000 の項目を抽出した。最終的 にこれを整理して、770項目からなるテストセットとしてまとめた。例文と関連文を合わせる と、合計で 1450 文ほどの規模のテストセットとすることが出来た。

また、本テストセットの実用性の検証と設問の修正のために、ハードウェアタイプの異なる 8 種の市販の英日機械翻訳システムを対象とした評価を行った。 
このテストセット中の各項目は、文番号、例文、その模範訳、○×で答えることが出来る質 問文、主として機械翻訳システムによる訳出例、例文と関連する言語現象を含む文、関連する 項目の番号、解説から成り立っている。テストセットの例を図 1 に示す。以下では、このテス トセットを用いた品質評価の手順、対象とする言語現象、テストセットの書式について述べる。

2. 1. 1 多品詞（品詞認定）

2. 1. 1. 2 名詞/助動詞

【番号】 2.1.1.2-1

【例文】 The trash can was thrown away.

【訳文】ごみカンは捨てられた。

【質問】 "can" が「カン/缶」のように名詞として訳されていますか？

【訳出例】 $\bigcirc$ (くず缶/ごみ容器/くず入れ) は(廃棄された/[投げ]捨てられた)。 $\times$ ごみは捨てられ得る。

【関連文】The last will was opened.「最後の遺言書は開けられた。」

【参照項目】2.1.1.2-2, 2.1.1.2-3

【解説】"can was" の並びから、"can" が助動詞でないことがわかる。

【番号】 $2.1 .1 .2-2$

【例文】 The trash can be thrown away.

【訳文】ごみは捨てられ得る。

【質問】 "can" が「〜できる/得る」のように助動詞として訳されていますか？

【訳出例】 $\bigcirc$ (くず/ごみ/くだらない人間) は(廃棄できる/[投げ] 捨てられることができる)。

【関連文】

× ごみカンは捨てられた。

【参照項目】2.1.1.2-1, 2.1.1.2-3

【解説】2.1.1.2-1 とは逆に、ここでは "can" は名詞ではなく助動詞。

図 1 英日機械翻訳システム用テストセットの例

\section{2 テストセットの利用法}

本テストセットは、以下の利用法を想定している。

(1) 評価対象となる英日機械翻訳システムを用意する。

(2) そのシステムでテストセット中の【例文】を翻訳する。

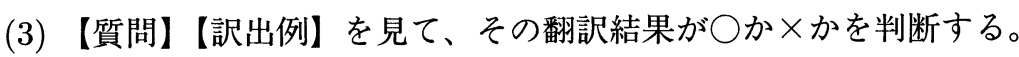

(4) システム開発者は、○×の分布からシステムの能力、開発段階を評価する。

特に、メと判断した項目に関連する文法・辞書を追加することで、システムの改良を図る。

（（5）ユーザは、各システムの○×の分布から、出力品質面での優劣を比較する。）

(6) 各項目についてさらに詳細に評価を行う場合は、【関連文】を利用する。

原則として翻訳結果と質問文を見るだけで $○$ を回答出来るようになっているが、【訳出例】 
(各訳出例には、質問に対する○×が予付与されている) を参照することによって、さらに容 易に判断が出来るようになっている。

本テストセットを用いて○×の分布を見ることで、システムの対応が不十分な (可能性があ る) 項目を容易に抽出できる。ただし本テストセットでは、各項目 (例文) 間の重要度、頻度な どの差異は考慮していないので、単純に○の数をカウントして正解率をシステム間で比較する ことは、本評価法の意図するところではない。

\section{3 テストセットの構成}

本テストセットは、機械翻訳システムが処理すべき様々な言語現象を含んだ英語例文 770 文 からなる。内訳と項目ごとの設問数を困 2 に示す。

品質評価の対象項目の収集に当たっては、網羅性を保証するトップダウンのアプローチと、 機械翻訳における問題点を実際の翻訳結果から抽出して、その問題性によって例文の粗密を決 定するボトムアップなアプローチを組み合わせている。

把握部に扔いては、英文法の解説書 (江川 1964, Hornby 1977, 小川 他 1991, 荒木 他 1992, 村田 1992) などを参考に英語の文法現象を収集し、そのレベルによって、品詞、文の部分構造、 文構造の 3 段階に分類した。特に動詞、形容詞、名詞に関してその基本的な用法を網羅するため に、ホーンビーの分類した文型 (Hornby 1977) を設問項目として採用した。ただしホーンビー のパターンの中でも、機械翻訳システムの品質評価において特に必要でないとみなした区分に ついては分類を省略している。同様に助動詞等の基本的な用法の中でも、機械翻訳において対 象となることが極めて稀であると思われるものについては省略した。

選択部においては、翻訳で実際に問題となる言語現象を、構文構造の曖昧性に関するもの と、コロケーション(他の語との共起による訳し分け)に関するものに分類した。

\section{4 テストセットの書式}

本テストセットの各項目の書式を図 3 に示す。なお、テストセット中で、[] で囲まれた部分 は挿入可能な表現を、（／）で囲まれた部分はいずれかを選択する表現を示す。たとえば、”A [B] C (D/E) F”という記号列は、“A B C D F”, “A B C E F”, “A C D F”, “A C E F”の 4 種の記号列を表す。

\section{4 日英機械翻訳システム品質評価用テストセット}

日英翻訳システム品質評価用テストセットも英日翻訳システム用と同様に、開発者が自己の システムの不備な点を発見するための評洒法であり、テストセット中の各例文に付与された設 問に答えることによって、客観的に評価を下せるように作られている。しかしながら、英日翻 
1 把握部

1. 1 品詞

1. 1 . 1

1. 1.2

1. 1.3

1. 1.4

1. 1.5

1. 1.6

1. 1.7

1. 1. 7 . 1 動詞・準動詞

1. 1. 7 . 2 助動詞

1. 1.8 関係詞

1. 1. 9 接続詞

1. 1.10 記号

1. 2 文の部分構造

1. 2. 1 不定詞

1. 2.2

1. 2 . 3

1. 2 . 4

1. 2.5

1. 2.6

1. 3 文構造

1. 3. 1

1. 3.2

1. 3.3

1. 3.4

1. 3.5

1. 3.6

1. 3.7

1. 3.8

1. 3.9

1. 3.10

分詞、分詞構文

動名詞

時制

数量表現

慣用表現

2 選択部

1. 3. 11 並列句

2. 1 構文

2. 1. 1 多品詞 (品詞認定)

2. 1.2

2. 2 コロケーション
小計 684

小計 355

15

27

25

42

54

40

48

37

25

26

16

小計 167

26

19

23

63

28

8

小計 162

19

16

19

21

16

10

4

16

9

7

25

小計 86

34

27

25

\section{図 2 テストセットの全体構成、項目別設問数}

訳と日英翻訳の技術レベルの違いに基づいて、英日用のテストセットとは少し異なった視点で テストセットの開発を行なった。実際のテストセットの例を図 4 に示す。

我々は、客観的評価を実現するテストセットの採用に加えて、日本語処理システムの開発者 の利便を考え、言語現象と処理モジュールとの対応を取ることができる形式の評価方法の開発 
【番号】 : 例文の番号

【例文】：例文 $(1$ 文のみ)

【訳文】模範訳（例文の日本語訳）

【質問】："A"が「B」のようにCとして訳されていますか？という形式の質問文 ・A：英語表現。" "で囲む。例文中のどの部分を翻訳することにポイン トがあるのかを表す。文全体の場合、また明らかな場合などは省略 する。

・B：日本語表現。「」で囲む。

- C : 内容や文法事項の補足説明（「習慣を表す表現」、「選択疑問文」

等）を記す。記述が長くなるものや、原因に言及する場合は、【解 説】に記述する。 ※必ず○か ×か (yes/no）で答えられる形式にする。

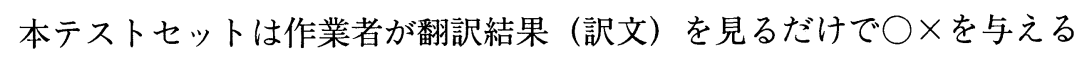
ことを前提としており、解析の詳細に直接言及することは避ける。

【訳出例】：許容される訳出例や誤訳例を列挙。

・正解例（yes）の文頭には○、誤例（no）の文頭にはメを付与する。

・ 1 行 1 文とし、原則として文全体を記述。

・必要ならば正/誤の理由（説明）も示す。

※各例は実際の機械翻訳システムの訳を参考にして作成した。

【関連文】：当該の例文と関連する言語現象を含んだ例文を挙げる。

・文の一部だけの記述は認めない。必ず文全体を記述する。

・例文の後に、「」で囲んだ訳文を記述する。

・補足事項（may/mightでの丁寧度の違いなど）がある場合は、訳文の後 に（）で囲んで記述する。

【参照項目】：本テストセット内の関連項目への参照ポインタ。原則として、相互参照と する。

※文番号を明示するのみで、文そのものは記述しない。

【解説】：その他の補足事項。フリーフォーマット。

\section{図 3 テストセットの書式}




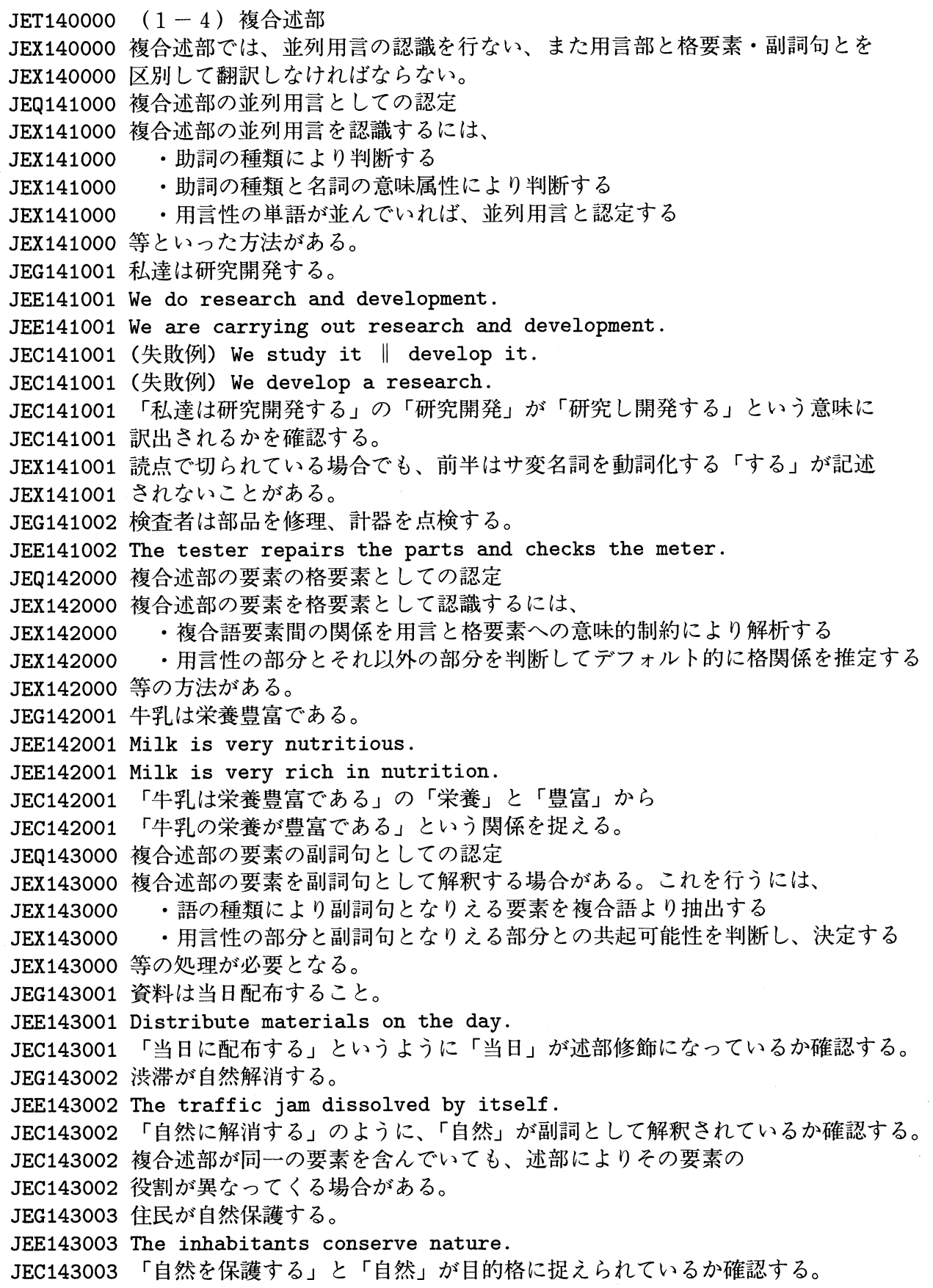

図 4 日英機械翻訳システム用テストセットの例 
を行なった。すなわち、評価用例文と、その翻訳結果を評価する手段 (設問) を提供するだけで なく、各言語現象に対応してシステムがどのような処理を行なっているかを把握するための解 説も付与している。解説によって示される言語現象の処理方法を利用して開発者は、そのシス テム全体としての言語現象の処理能力を評価するとともに、処理の各段階が充分な能力を持っ ているかどうかを把握できる。

具体的には言語現象を約 40 種類に大別し、その各項目について問題となっている言語現象 をどのように処理しているかを調べるための解説が付加されている。言語現象の項目リストを 困 5 に示す。ここでは必要に応じて、用いている知識や処理結果の取り扱い等も併せて説明さ れる。各項目内の個別の言語現象については、その言語現象を含む日本語文、その英訳、ここ で確認するべき要素の解説が記述されている。設問数は約 330 、機能確認のための対訳例は、 約 400 文の構成となっている。

また、開発者がこのテストセットを使用する際の利便性を考え、テストセットの書式を揃 え、各文にインデックスをつけることにより、機械上での検索を容易に行なえるようにした。上 記の各項目に付けられたインデックスは基本的に困 6 のような構造である。困 6 の??????の部 分には、数字またはアルファベットが使用される。最初の 2 文字がタイトルまたはサブタイト ルの章番号を表す。次の 3 文字が、各項目中の設問に付与された番号であり、設問は最大 3 階 層になっている。最後の 1 文字が例文及び翻訳例の文番号を示す。解説、コメントはその対象 とする項目と同じ文番号となる。

これらのインデックスを検索のキーとして、各種のＯSの検索コマンドを使用することによ ク、機械翻訳にかけるための原文のみの抽出や、項目リストの抽出など、簡単に必要な部分だ けを抜きだして使用することが出来る。使用例を図 7 に示す。

\section{5 おわりに}

本稿では、機械翻訳システムの翻訳品質を開発者の視点から評価する手法を提案した。この 手法は、評価用の各例文に質問と解説を付加したテストセットを用いることにより評価過程を 明確化した客観的品質評価法である。本稿で提案したテストセットは、評価用の例文に、その 人間による訳、システムの出力を評価するための設問、(もしあった場合には) 関連する文、文 法事項の解説等を付与したものである。例文は基本的な言語現象と、機械翻訳において現在課 題となっている言語現象を網羅することを念頭において収集された。

テストセット中の設問は評価するべき点を明確にするように作成されている。各例文の翻訳 結果が与えられると、システム開発者はその例文に付与されている設問に答えていくだけで、 自己のシステムの評価を行なうことが出来る。設問は $\bigcirc \times$ 式であり、評価者によって判断が分 かれないように作られている。これにより、客観的な評価が可能となる。さらに、解説を参照 することにより、システム開発者は自己のシステムがどの言語現象を処理できないかを正確に 


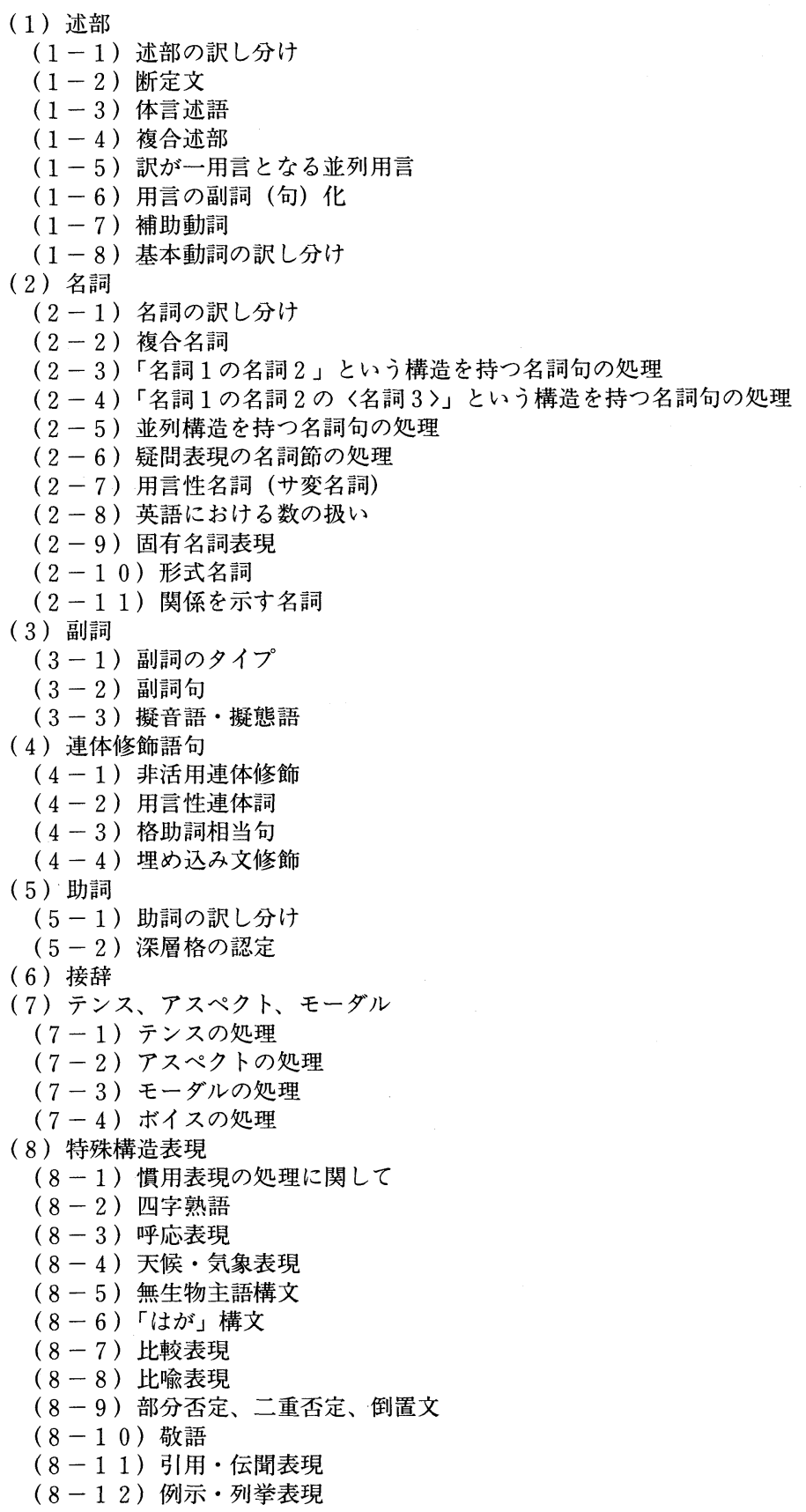

図 5 テストセットの項目リスト 


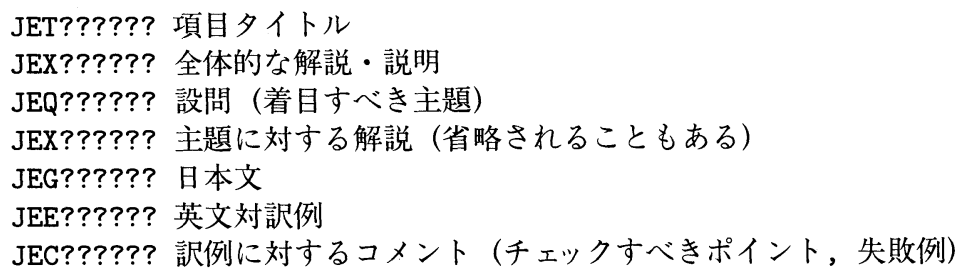

\section{図 6 インデックスの構造}

認識することが出来る。

ここで提案した英日及び日英翻訳システム用のテストセットは無料で一般に公開されて いる。我々は、この評価法が機械翻訳システムの一層の発展の一助となることを期待してやまない. 
【使用例】（日英評価基準のファイル名が MT_EVAL_JE.doc であるとする）

・まず文法項目の目次を調べる。

$\$$ grep JET MT_EVAL_JE.doc

\begin{tabular}{|c|c|}
\hline JET100000 & （1）述部 \\
\hline JET 100000 & (1-1) 述部の訳し分け \\
\hline JET120000 & (1 - 2) 断定文 \\
\hline JET 130000 & (1-3) 体言述語 \\
\hline JET140000 & (1-4) 複合述部 \\
\hline
\end{tabular}

・ $(1-4)$ の「複合述部」にどのような設問があるかを調べる。

\$ grep JEQ14 MT_EVAL_JE.doc

JEQ141000 複合述部の並列用言としての認定

JEQ142000 複合述部の要素の格要素としての認定

JEQ143000 複合述部の要素の副詞句としての認定

・次に「副詞句」のところにどのような例文があるか調べる。

\$ grep JEG143 MT_EVAL_JE.doc

JEG143001 資料は当日配布すること。

JEG143002 渋帯が自然解消する。

JEG143003 住民が自然保護する。

・例文の参考訳を調べる。

$\$$ grep JEE143 MT_EVAL_JE.doc

JEE143001 Distribute materials on the day.

JEE143002 The traffic jam dissolved by itself.

JEE143003 The inhabitants conserve nature.

・例文 JEG143001 が何を調べたいの例文なのかを調べる。

\$ grep JEC143001 MT_EVAL_JE.doc

JEC143001「当日に配布する」というように「当日」が述部修飾になっているか確認する。

・例文 JEG143001 をMTで訳させた結果が、コメント JEC143001 の確認事項を満たして いれば評価結果を ○、さもなければ評価結果を $\times$ とする。

(JEE143001 は参考訳であり、必ずしもその通りの訳になっていなくとも良い)

図 7 テストセットの機械上での使用例 


\section{参考文献}

荒木一雄 他 (1992). 現代英文法辞典. 三省堂.

江川泰一郎 (1964). 英文法解説 (改訂新版). 金子書房.

Hornby, A. S. (1977). 英語の型と語法 (第 2 版). オックスフォード大学出版局 (東京).

池原悟・小倉健太郎 (1990). “日英機械翻訳における機能試験項目の検討.”電子情報通信学会 1

990 年秋期全国大会論文集 D-68.

池原悟 他 (1994). “言語表現体系の違いに着目した日英機械翻訳機能試験項目の構成.”人工知

能学会誌, 9 (4).

井佐原均 他 (1992). “J E I D A 機械翻訳システム評価基準 (品質評価編) 一英日翻訳の品質評

価項目の検討と評価用コーパスの作成一.”自然言語処理研究会 96-11, 情報処理学会.

Isahara, H. et al (1994). "Technical Evaluation of MT Systems from the Developer's Point of View: Exploiting Test-Sets for Quality Evaluation," In Proceedings of the AMTA-94

(First conference of the Association for Machine Translation in the Americas).

Isahara, H. (1995). "JEIDA's Test-Sets for Quality Evaluation of MT Systems - Technical Evaluation from the Developer's Point of View." In Proceedings of the MT Summit V. 石崎俊・井佐原均 (1988). “日本語文の複雑さの定性的・定量的特徵抽出.”自然言語処理研究会 67-6, 情報処理学会.

村田勇三郎 (1992). 機能英文法. 大修館書店.

成田一 (1988). “機械翻訳における構造処理能力の評価.”自然言語処理研究会 69-1, 情報処理 学会.

日本電子工業振興協会 (1985). “機械翻訳例文資料.” 機械翻訳システムの調査研究 60-C-513.

日本電子工業振興協会 (1988). 機械翻訳システムの調查研究.

日本電子工業振興協会 (1993). 機械翻訳システムの実用化に関する調査研究 93-計-6.

日本電子工業振興協会 (1994). 自然言語処理技術の動向に関する調查報告書 94-計-4.

日本電子工業振興協会 (1995a). 自然言語処理技術の動向に関する調査報告書 95-計-3.

日本電子工業振興協会 (1995b). 機械翻訳システム評価基準ーー品質評価用テストセットーー 95-計-17.

野村浩郷・井佐原均 (1992). “機械翻訳の評価基準について.” 自然言語処理研究会 89-9, 情報処 理学会.

Nomura H. and H. Isahara (1992a). "JEIDA's Criteria on Machine Translation Evaluation." In Proceedings of the International Symposium on Natural Language Understanding and AI.

Nomura H. and H. Isahara (1992b). "JEIDA Methodology and Criteria on Machine Translation Evaluation." In Proceedings of the MT Evaluation Workshop. 
小川芳男 他 (1991). よくわかる英文法 [再訂新版]. 旺文社.

Tomita M. (1992). "Application of the TOEFL Test to the Evaluation." In Proceedings of the MT Evaluation Workshop.

White, J. S. et al. (1994). "The ARPA MT Evaluation Methodologies: Evolution, Lessons, and Future Approaches." In Proceedings of the AMTA-94 (First conference of the Association for Machine Translation in the Americas).

\section{略歴}

井佐原 均: 1978 年京都大学工学部電気工学第二学科卒業. 1980 年同大学院修 士課程修了. 工学博士. 現在, 郵政省通信総合研究所関西支所知的機能研究室 長. 自然言語処理, 機械翻訳の研究に従事.

内野 一: 1987 年茨城大学工学部情報工学科卒業. 1989 年同大学院修士課程修 了. 現在, NTTコミュニケーション科学研究所研究主任. 自然言語処理, 機 械翻訳の研究に従事.

荻野 紫穗: 1988 年東京女子大学大学院文学研究科修士課程修了. 現在, 日本 I BM東京基礎研究所に勤務. 自然言語処理, 機械翻訳の研究に従事.

奥西 稔幸: 1984 年大阪大学基礎工学部情報工学科卒業. 現在, シャープ株式会 社情報システム事業本部情報商品開発研究所に勤務. 機械翻訳システムの研 究開発に従事.

木下 聡: 1983 年東京工業大学工学部情報工学科卒業. 1985 年同大学院修士課 程修了. 現在, (株) 東芝研究開発センター情報・通信システム研究所に勤務. 自然言語処理, 機械翻訳の研究に従事.

柴田 昇吾: 1985 年早稲田大学理工学部電子通信学科卒業. 1987 年同大学院修 士課程修了. 現在, キヤノン株式会社情報メディア研究所に勤務. 自然言語処 理の研究に従事.

杉尾俊之: 1982 年熊本大学工学部電子工学科卒業. 現在, 沖電気工業 (株) 研究 開発本部関西総合研究所に勤務. 機械翻訳システム, 自然言語処理の研究開 発に従事.

高山 泰博: 1985 年九州工業大学工学部情報工学科卒業. 1987 年九州大学大学 院修士課程修了. 現在, 三菱電機 (株) 情報技術総合研究所に勤務. 自然言語 処理の研究に従事.

土井 伸一： 1985 年東京大学教養学部基礎科学科第二卒業. 1990 年同大学院総 合文化研究科博士課程満期退学. 現在, 日本電気 (株) 情報メディア研究所音 声言語研究部主任. 自然言語処理, 機械翻訳の研究開発に従事.

永野 正: 1987 年慶応義塾大学電気工学科卒業. 1989 年同大学院修士課程修了. 
現在松下通信工業 (株) カーシステム事業部に勤務.

成田 真澄: 1987 年津田塾大学大学院修士課程修了. (株) リコー情報通信研究 所に勤務. 機械翻訳の研究に従事.

野村 浩郷: 1967 年大阪大学工学部通信工学科卒業. 1969 年同大学院修士課程 修了. 工学博士. 日本電信電話公社基礎研究所を経て, 現在, 九州工業大学情 報工学部教授. 言語知能, 知能ネット, 計算言語学, 機械翻訳の研究に従事.

(1995 年 9 月 5 日受付)

(1995 年 11 月 28 日 採録) 